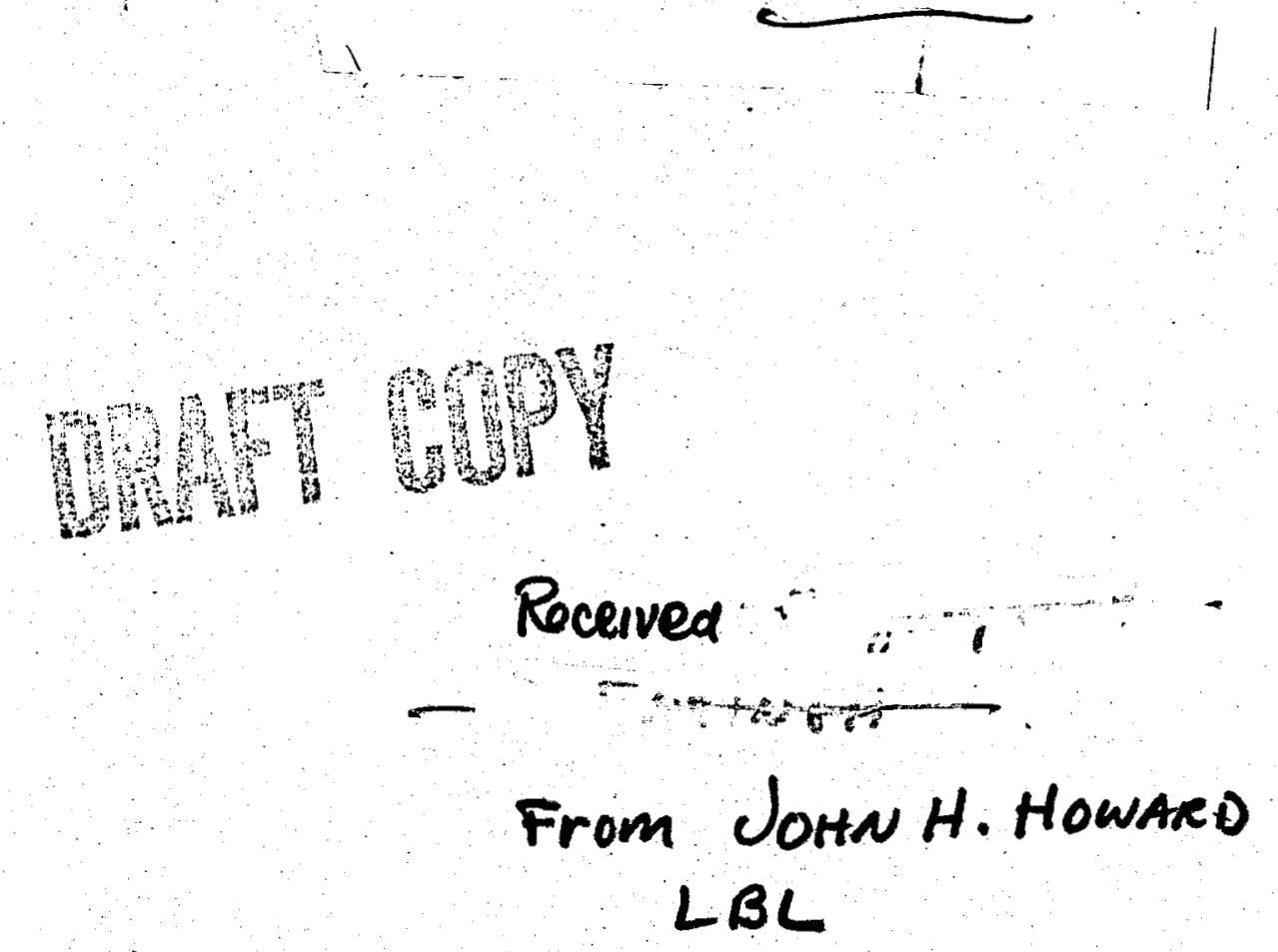

\title{
GEOTHERMAL ENERGY DATABOOK \\ FOR THE \\ WESTERN UNITED STATES
}

by

S.L. Phillips, M. Tavana, K. Leung, S.R. Schwartz

National Geothermal Information Resource

Lawrence Berkeley Laboratory

University of California

Berkeley, CA 94720 


\section{DISCLAIMER}

This report was prepared as an account of work sponsored by an agency of the United States Government. Neither the United States Government nor any agency Thereof, nor any of their employees, makes any warranty, express or implied, or assumes any legal liability or responsibility for the accuracy, completeness, or usefulness of any information, apparatus, product, or process disclosed, or represents that its use would not infringe privately owned rights. Reference herein to any specific commercial product, process, or service by trade name, trademark, manufacturer, or otherwise does not necessarily constitute or imply its endorsement, recommendation, or favoring by the United States Government or any agency thereof. The views and opinions of authors expressed herein do not necessarily state or reflect those of the United States Government or any agency thereof. 


\section{DISCLAIMER}

Portions of this document may be illegible in electronic image products. Images are produced from the best available original document. 


\section{Preface}

During the past ten years much progress has been made in the United States to develop geothermal energy and to construct power plants. Current electrical power produced is 608 MWe at The Geysers in California which obtains steam to drive turbines from steam wells. However, the major new sources of geothermal energy in the next decade are expected to be hot brine systems located in the Western United States. Data on the power potential and progress toward utilization is needed for these new areas to identify impediments to utilization and to forecast power on-line in the next decades. However, the data is widely scattered and largely unevaluated, thereby impeding the analysis for predictions of power production in the decades 1980, 1990 and beyond the year 2000.

The National Geothermal Information Resource (GRID) project of the Lawrence Berkeley Laboratory was initiated in 1974 with the objective of compiling both basic and site-specific data on major aspects of geothermal energy utilization. The objectives of the database are:

1. To compile information and numerical data for each major geothermal prospect. The data will include that which is measured or estimated (e.g., calculated, inferred, extrapolated); estimated values will be identified as such by an appropriate tag. This is a current on-going activity.

2. To evaluate the data with the idea to recommend values that can be used as reference data for each site.

3. To establish a computer-aided classification file of major U.S. geothermal prospects which lists each site according to the degree of development toward commercial power production. 
4. To develop a list of activity indicators for monitoring the progress of power production with the idea that these will serve as a basis for prospect classification.

5. To examine new state-of-the-art electric power technologies developed within and outside the geothermal energy field which may enable a significant reduction in the cost of geothermal power production.

6. To make recommendations for new or additional site-specific data needs where necessary for each prospect. 


\section{Abstract}

This report consists of available information for electric power production covering selected major geothermal prospects in the western United States; emphasis is on the state of California. Detailed technical, economic and institutional information which is used mainly to evaluate a geothermal area for its potential to produce electrical power is presented for 21 major geothermal prospects. Summary data tables with selected data elements are provided for these 21 geothermal sites as well as over 40 other sites in California to show the current status of each prospect, impediments to its developments and areas of additional data needs. Maps are also included to show the location of each geothermal area. Further additional data, such as location of electric power plants, transmission lines, highways and water transportation routes, quantity and quality of groundwater, land use, land ownership, etc. are presented in the form of maps and tables for California and Nevada. 
Acknowledgement 
Not the fact avails, but the use you make of it.

Ralph Waldo Emerson 


\section{TABLE OF CONTENTS}

Preface

Abstract

Acknowledgement

A. Introduction

B. Site-Specific Data

C. Scope of Databook

D. Technology Developments

E. Data and Information Sources

F. Summary and Conclusions

G. Table of Units and Conversions

H. References

Appendix I: Summary of Current Site-Specific Data for the Western United States

Appendix II: Energy Conversion File (ENCON)

Appendix III: California and Nevada Geothermally-Related Data 


\section{LIST OF TABLES*}

TABLE NUMBER

$\therefore$ PAGE

\section{1}

2

3

4

5

6

7

1.1

I.2

I. 3

I. 4

I. 5

I. 6

I.7

1.8

I.9

1.10

I.11

I.12

I.13

I.14

I.15

1.16

1.17

I.18

1.19

I. 20

I.21

1.22

I. 23

I. 24

I. 25

I. 26

I. 27

III. 1

III. 2

III. 3

III. 4

Selected Geothermal Areas in The Western United States

Expected Power Plant Construction in the Western United

States

Geothermal Drilling in California in 1979

Geothermal Drilling in California in 1978

Geothermal Drilling in Nevada to 1977

Geothermal Leases in California

Issued Federal Leases - California, As of Dec. 5, 1978

Reservoir Temperature and Acreage for Major Geothermal

Areas in California

Summary Data for California/Brawley

Summary Data for California/Coso Hot Springs KGRA

Summary Data for California/East Mesa

Summary Data for Cal ifornia/The Geysers/Lake, Sonoma

Summary Data for California/Glass Mountain

Surmary Data for California/Heber

Summary Data for California/Lake City-Surprise Valley

Summary Data for California/Lassen KGRA

Summary Data for California/Mono-Long Valley

Summary Data for California/Salton Sea

Summary Data for California/Sespe Hot Springs KGRA

Summary Data for California/Skagg's Hot Springs

Summary Data for California/Sulphur Bank Mine

Sumnary Data for Cal ifornia/Wendel1-Amedee KGRA

Summary Data for Hawaii/Puna

Summary Data for Idaho/Bruneau-Grandview

Reservoir Temperature and Acreage for Major Geothermal

Areas in Nevada

Summary Data for Nevada/Beowawe Hot Springs

Summary Data for Nevada/Ruby Valley

Summary Data for New Mexico/Valies Caldera/Baca

Location \#1

Summary Data for Oregon/Alvord

Summary Data for Utah/Cove Fort-Sulphurdale

Summary Data for Utah/Monroe-Joseph

Summary Data for Utah/Roosevelt Hot Springs/Milford

Summary Data for Utah/Thermo

Summary Data for Washington/Mt. Baker-Baker Hot Springs

Electric Power Plants in California, 1976.

Electric Generating Capacity By Primary Fuel, 1977

Production of Electric Energy By Sources, 1977

Major Electric Utilities, 1976.

*Tables on ENCON file in Appendix II are not listed here. 


\section{LIST OF FIGURES}

FIGURE NUMBER

PAGE

I.I

I. 2

I.3

I. 4

I.5

I. 6

I.7

I. 8

I.9

I. 10

III. 1

III. 2

III. 3

III. 4

III. 5

III. 6

III. 7

III. 8

III.9

III.10

III. 11

III.12

III. 13

Geothermal Areas in California

Map of The Geysers-Calistoga KGRA

Map of Imperial Valley KGRA's

Map of Hawai i

Location of Geothermal Activity, Idaho

Location of Geothermal Activity, Nevada

Location of Geothermal Activity, New Mexico

Location of Geothermal Activity, Oregon

Location of Geothermal Activity, Utah

Location of Geothermal Activity, Washington

Location of Electric Power Plants in California, 1976

Electric Utility Service Areas in California

Interstate Transmission of Electricity, 1974

Major Transmission Lines

Major Rail, Highway and Water Transportation Routes, 1974

Major Rivers, Lakes and Reservoirs

Groundwater Areas in California and Nevada

Land Use in California, 1971

Cropland, 1967

Forestland, 1967

Pasture and Rangeland, 1967

National Park System

Population Density, 1975 
The Lawrence Berkeley Laboratory is funded by the Department of Energy to establish a National Geothermal Information Resource (GRID). The project was established in 1974 to evaluate and disseminate information on geothermal energy in the following major areas: (1) the thermodynamic and transport properties of aqueous solutions to high temperatures and pressures, (2) utilization of the geothermal resource, and (3) environmental aspects, mainly hydrogen sulfide emissions and subsidence. The content of this databook is limited to the available current information for electric power production covering 21 major areas in the western United States, and over 40 sites in California.

\section{A. Introduction}

The objective of this work is to provide a single, comprehensive database containing evaluated reference data useful in assessing geothermal sites for their potential to produce electrical power. The compilation and evaluation constitute a databook of current information for plant construction, modeling, research and development for conversion of geothermal energy to electric power production. The results of this work include identification of areas where data are lacking or are inadequate and where technology development is needed. The interest in site-specific data stems from two important concerns: (1) forecasts of power production related to local, state and national goals, for example, the second report on geothermal energy by the Interagency Geothermal Coordinating Council which contains forecasts for power on-line to the year 2000 and beyond (Ref. 1), and (2) the assessment of each site to produce power in an economic manner for a 20 to 30 -year time period. An example of (2) is the design of an electric generating 
system using the following data: (a) temperature of the fluids produced, (b) chemical composition of the reservoir fluids, (c) availability of cooling water, (d) current land usage, (e) flow rates sustainable by the production wells, (f) cost of drilling within the area, (g) well spacing for production and injection, (h) turbine system to be used, and (i) general operating costs in the area. See for example Reference 2.

The currently available data for geothermal sites is widely scattered, uneven in quantity and quality, and ranges from extensive for The Geysers and East Mesa areas to sparse for Alvord and Lassen. This is especially true for sites outside of California. The best available sources have been used to gather the data and every attempt has been made to assure that figures and facts quoted are the most accurate and up-to-date. Data are compiled from the original sources as much as possible, and new or revised data is added after its receipt.

There is an increasing number of reports covering new regulatory processes and new techniques from research and development to make geothermal power production more economical than at present, and to facilitate obtaining permits. Selected portions of this work are included here to provide relevant information on exploration, drilling, environmental and institutional aspects, and utilization for power production.

No systematic attempt was made to convert numerical data to a consistent set of units; however, a conversion table is included for convenience of the reader. Section $G$ lists these units and conversion factors required for other units. 
Material contained here was obtained from publications, reports, correspondence, by visits and other contacts. While it is our intent that this database be as comprehensive as possible, it is recognized that no compilation can be exhaustive. In this context, the reader is urged to communicate important omissions and comments to the National Geothermal Information Resource for inclusion in a subsequent revision.

Additional information on site-specific data is obtained from Geothermal Energy Resources in California: Status Report and Appendix (Ref. 3), Geothermal Handbook (Ref. 4), Site-Specific Analys is of Geothermal Development - Data Files of Prospective Sites, Vol. III (Ref. 5), Cumulative Geothermal Statistical Bid Recap, CY 1974-1978 (Ref. 6), Geothermal Power Plants of the United States:

A Technical Survey of Existing and Planned Installations (Ref. 7), Geothermal Exploration and Development in Nevada Through 1973 (Ref. 8,29), GEOTHERM Database (Ref. 9), Proceedings First Geopressured Geotliermal Energy Conference (Ref. 10), Regional Hydrothermal Commercialization Plan (Ref. 11), and Analysis of Requirements for Accelerating the Development of Geothermal Energy Resources in California (Ref. 19). 


\section{B. Site-Specific Data}

Data for geothermal sites in the western United States are presented in three appendixes at the end of this report. Appendix $I$ is a summary of resource characteristics which are recommended for use in assessing each site for its potential to produce electric power, or for direct utilization. This information is the best currently available, or that which is most widely used; such data may subsequently be changed to reflect new measurement selected if necessary from a range of values. References are given to the sources used in arriving at the recommended value. The same procedure is used for non-numerical information.

Appendix II consists of an Energy Conversion (ENCON) database compiled on a text-editing system; the compilation includes numerical values, tables and other information obtained from many referenced sources. All of the information sources are referenced by a short code that has been adopted in our bikliographic file. The short code gives the name of the author (or the first author if more than one author) or the name of the corporation publishing the report and the year of publication. Site-specific data for 21 geothermal prospects is presently stored on the ENCON file. Table 1 lists major geothermal prospects in the western United States expected to be covered; those already on ENCON file are identified by an asterisk.

The data contained in the ENCON file include the following major categories:

General Information consists of a record number, site name, location, developer and description; and the estimated electric power potential.

Reservoir Parameters covers fluid temperature; well cost; field flow rate; well life; non-condensible gas content; steam quality; well thead temperature; well flow rate; fluid enthalpy. 
Operational Parameters contains information on plant size; plant cost; power cost to load center; type of power cycle; operating and maintenance cost; well spacing; parasitic power; well replacement rate; heat transfer coefficient; heat rejection system; make-up water cost; wet bulb temperature. Hot Water Transmission (Direct Utilization) section covers the nonelectric utilization of the resource and includes materials used for pipe, pipe fitting, insulation, casing, pipe support and pump; type of valves; method of installation of pipes, insulation, casing, pipe support and pump.

Field Baseline Data consists of thermal water temperature and flow rate; inferred reservoir temperature; electrical resistivity; heat flow; thermal gradient; gravity survey value; seismic noise correlation; pumping power required; scale control; foul ing factor; corrosion control; well logging data, well test data, drilling mud types, acoustic log, temperature log, caliper log, electrical resistivity log, dipmeter, log interpolation, bottomhole pressure; well drilling date, well completion type, depth to production, wellhead pressure; materials used for piping, valves and throttle plates; number of producing wells; number of non-producing wells.

Environmental Aspects are gas data, sample date, and $\mathrm{H}_{2} \mathrm{~S}, \mathrm{CO}_{2}$ and other gases contained in sample; fluid data, sample date, total dissolved solids, boron, silica, bicarbonate, carbonate and sulfate content of fluid, fluid pH; waste water disposal method; pre-disposed treatment method; subsidence; status of environmental impact report (EIR) and environmental impact statement (EIS).

Reservoir Engineering includes recharge source; rock porosity; reservoir rocks; thermal conductivity; permeability. 
Land Use Factors consists of well spacing; Iand improvements needed; existing land use; physical conditions of area; land use planning; fresh water supply; water rights; proximity to markets/transmission lines.

Legal Aspects are preleasing procedures; exploration permits; leasing, lease holders, royalty payment, restrictions; depletion allowance; government regulations, loan guarantee, primary term duration, renewal leasehold periods, work requirements, and data monitoring; water laws, pollution control and reinjection control; air laws, emissions control; state income tax; federal income tax; bond interest.

Injection Well Data includes fluid flow rate; well stimulationl reinjection power required.

Appendix III contains selected maps and tables to include location of roads and railways, existing land use, availability of water, and proximity to transmission lines. The data in this section is presently limited to California and Nevada. 
Table 1. Selected Geothermal Areas in the Western United States (Ref, 61)

Alaska

No. of Acres

1. Akutan Hot Spring

2. Geyser Spring Basin KGRA

20,960

3. Okmok Caldera KGRA

44,800

4. Pilgrim Springs KGRA

22,400

5. Port Moller

Arizona

1. Casa Grande

2. Chandler

3. Clifton KGPA

4. Gillard Hot Springs KGRA

780

5. Hookers

2,920

California KGRA

1. Beckwourth Peak

2,558

2. Bodie

640

*3. Brawley

*4. Coso Hot Springs

28,886

5. Dunes

*6. East Mesa

106,798

7,680

7. Ford Dry Lake

38,365

*8. Geysers-Calistoga

7,687

9. Glamis

*10. Glass Mountain

376,030

*11. Heber

25,505

33,287

12. Knoxville

*13. Lake City-Surprise Valley

58,568

14,702

72,940

*14. Lassen Hot Springs

78,642

15. Little Horse Mounta in

1,196

16. Love Lady Ridge

6,879

*17. Mono-Long Valley

460,256

18. Randsburg

19. Saline Valley

12,880

3,200

*20. Salton Sea

95,824

21. Sespe Hot Springs

7,034

22. Hendel-Amedee

23. Witter Springs

17,932

18,152

24. Hestmorland (not a KGPA)

Colorado

1. Alamosa County KGRA

2. Mineral Hot Springs KGRA

3. Poncha KGRA

5,765

4. Valley View Hot Springs KGRA

5. San Luis Valley 
No. of Acres

Hawaii

*1. Puna

Idaho

1. Boise

*2. Bruneau KGRA

*3. Castle Creek KGRA

4. Crane Creek KGRA

5. Is land Park KGRA

6. Mounta in Home KGRA

7. Preston

8. Raft River KGRA

9. Vulcan Hot Springs KGRA

10. Weiser-Crane Creek

11. Yell lows tone KGRA

12. Conda KGRA

Louisiana

1. Acadia Parish

2. Calcasieu

3. Cameron

Montana

1. Boulder Hot Springs KGRA

6,343

2. Corwin Springs KGRA

$20,349^{\circ}$

3. Ennis Lake

4. Marysville KGRA

5. Hest Yellows tone KGRA

6. Warm Springs

19,200

- 12,763

Nevada KGRA

1. Baltazor

5,617

*2. Beowawe

33,224

3. Black Rock Desert (not a KGRA)

4. Brady-Hazen

98,508

5. Colado

6. Continental Lake (not a KGRA)

640

7. Darrough Hot Springs

8. Dixie Valley

8,363

9. Double Hot Springs

38,348

10. Elko Hot Springs 
11. Fly Ranch

20,759

12. Fly Ranch Northeast

13. Gerlach

14. Gerlach Northeast

26,326

7,971

8,549

15. Hot Springs Point

2,561

17. Lach Hot Springs

12,846

18. Moana Springs

5,120

19. Monte Neva Hot Springs

10,302

20. Pinto Hot Springs

*21. Ruby Valley

8,015

5,743

22. Rye Patch

801

23. Salt Wells Basin

19,232

24. San Emidio Desert

25. Silver Peak

26. Soldier Meadow

27. Steamboat Springs

7,678

5,117

5,966

8,911

28. Stillwater-Soda Lake

225,260

29. Trego

30. Wabuska

31. Warm Springs

32. Wilson Hot Springs

7,013

11,520

3,812

1,294

New Mexico

1. Mamby's Hot Spring

2. Animas Valley

* 3. Baca Location No. 1 KGRA .

168,761

4. Gila Hot Springs KGRA

3,202

5. Kilbourne Hole KGRA

6. Lightning Dock KGRA

25,134

23,552

7. Lower Frisco Hot Springs KGRA

5,760

8. Guadalupe

9. San Ysidro KGRA

10. Socorro Peak KGRA

11. Truth or Consequences

1,915

89,716

12. Radium Springs KGRA

9,813

13. Columbus

Oregon KGRA

*1. Alvord

2. Beulah (not a KGRA)

176,835

3. Bel knap-foley Hot Springs

5,066

4. Breitenbush Hot Springs

13,445

640

5. Burns Butte

7,579

7. Crump Geyser

8. Glass Butte (not a KGRA)

85,663

9. Harney Lake

10. Klamath Falls

50,300 
11. Lakeview

12. McCredie Hot Springs

12,165

3,659

8,671

14. Newberry Crater

31,284

13,631

15. Summer Lake Hot Springs

22,998

Texas

1. Brazoria

2. Corpus Christi

3. Kenedy

4. Matagorda

Utah KGRA

1. Brigham City (not a KGRA)

*2. Cove Fort-Sul phurdale

3. Crater Springs

4. Lund

5. Meadow-Hatton

6. Minersville (not a KGRA)

*7. Monroe-Joseph

8. Navajo Lake

9. Neels (not a KGRA)

10. Newcastle

*71. Roosevelt Hot Springs

24,074

17,321

3,840

1,927

16,364

2,522

2,636

29,791

*12. Thermo Hot Springs

Washington

*1. Baker

2. Indian Heaven

2,547

3. Gifford Peak

4. Kennedy Ho': Springs

3,311

5. Mount St. Helens

29,754

Wyoming

1. Afton

2. Strawberry

*Presently on ENCON file 


\section{Scope of Databook}

The data covered in this work is generally from 1970 to 1979. The first date was selected because data on geothermal utilization began to be generally available in 1970, for example, at the U.N. Conference in Pisa, Italy. Information prior to 1970 includes leasing, drilling, reservoir properties and power plant performance. Besides sitespecific geothermal data, this databook also contains selected information on geothermal sites that meet either or both of the following criteria: (1) research and development in geothermal energy and related fields that may have application to a specific site. New drill bits and testing of additives to control scaling are examples of research and development. (2) Site-specific but non-geothermal data that is important to the utilization of an area. Examples of (2) are location of the nearest power lines, roads and towns, existing land use, availability of water, and ambient levels of hydrogen sulfide. 
D. Technology Developments

Costs associated with electric energy production by geothermal power plants might be reduced by research and development programs to include the following:

(1) Improvement of geophysical surveys for finding and estimating the potential of geothermal reservoirs.

(2) Reducing capital costs incurred in field development, to include production wells, reinjection wells and field piping.

(3) Reducing the capital cost of power plants by improving or developing new processes and equipment design methods; examples are work on heat exchangers and hydrogen sulfide scrubbers.

(4) Improvement of the plant's specific net energy which will reduce well field costs because less brine and fewer wells will be required for a given power rating. Improvement in turbine efficiency and condenser performance are examples.

(5) Reducing the scheduled and unscheduled dcwintime of the plant and hence increasing the plant availability by improvement of equipment reliability and extending service life. A prime example is control of corrosion and scaling caused by geothermal brine in pifing, valves and other equipment which are in contact with brine.

(6) Development of new materials to contain, process, and generally handle high temperature and highly corrosive environments that are encountered in geothermal brines. In this context, research is needed for the following:

1. Geophysical Exploration

In view of the high drilling costs, geophysical well surveys play 
an important role in estimating the power potential of geothermal reservoirs. Geophysical exploration includes surface electrical resistivity surveys, seismic ground noise surveys, passive micro-earthquake monitoring surveys, magneto-telluric surveys and all other geophysical surveys including airborne techniques. However, in order to employ these techniques in assessing a geothermal reservoir, correlations between the measurement and the physical properties of the rock types that are commonly found in geothermal reservoirs must be developed. The existing correlations developed for the oil and gas industry apply only for the rocks in which oil and gas are commonly found, such as clastics and carbonates (Ref. 30). Some geothermal reservoirs may occur in such rock types, but probably a large fraction will occur in volcanic rocks (lief. 30 ). Research is needed to establish correlations between measurab?e properties such as electrical resistivity and acoustic wave speed, and properties which need to be kriown, such as porosity, water salinity, temperature and well productivity. The Colorado School of Mines has published data on the seismic velocities and resistivities of geothermal. reservoir rocks obtained from the Colombia Plateau volcanic basin, New Mexico Jemez Mountains, volcanics from south central Nevada, and Cascade range in Oregon. A strong dependence of seismic velocity and resistivity of Cenozoic Volcanic rocks on porosity was demonstrated (Ref. 30,31 ). 2. Orilling and Field Development

A great portion of the expense in geothermal power production is due to costs associated with well drilling, well completion and well logging. It costs about twice as much to drill a geothermal well as it does to drill a comparable oil or gas well. This is partly due to the high temperature corrosive 
environment combined with the different geothermal formations and other reservoir parameters associated with geothermal wells which place severe limitations on the use of existing equipment and techniques based on those used in gas and oil industry. Most of these limitations are common to all prospects. On the other hand, some drilling problems can be related to a specific characteristic of a particular prospect. These might include terrain, salinity of the reservoir fluid, high temperature or rock hardness. Research is needed to develop new materials, equipment and techniques appropriate to a geothermal environment. These include the following:

\section{1 - Drill Bits}

In geothermal drilling, due to high temperature effects on materials, bits have a much shorter lifetime than in gas and oil drilling. Furthermore, the shortened bit life represents only one part of the increased drilling costs. Penetration rates are generally lower since the bits are run at reduced load in order to prevent catastrophic failure. Additionally, bit replacement causes hours of downtime which not only means more drilling costs. but also leads to other problems. See the review of patents on bit design in Reference 32. Improvements in seals and bearings, particularly in terms of increase in bit life is needed.

A study of cases of premature drill-bit failure in the geothermal well drilling done by Terra Tek, Inc., (Ref. 33) concluded that research on developing drill bit materials for operation at higher temperatures could achieve significant gains in the bit life. For other research activities on drill bits, the reader is referred to Reference 34,35 .

\section{2 - Downhole Motors}

Development of downhole motors could provide an ideal drilling method. 
Motors reduce the chances of pipe twist-off, provide potentially more power to the rockface, and are convenient for directional drilling (Ref.38). Currently available downhole motors are restricted for their use to specialized applications such as directional drilling even for low temperature oil and gas wells. The main problems causing these limitations are short life due to inadequate or short seal life and high rotational speed. An added problem for geothermal applications is the fact that all elastometric components degrade very rapidly at even very modest temperatures Both lifetime and load capacity of downhole motors need improvement. Research is also needed in developing downhole motors with the capability to monitor ans correct unwanted deviations or to drill directionally into the producing formation.

2.3 - Drilling Fluid and Lost Circulation

The role of drilling fluids in the geotrermal environment is identical to that in the case of oil and gas drilling. The high temperature of the formations in geothermal drilling, however, imposes a major limitation on such fluids. As the temperature rises, the mud viscosity increases, resulting in an altered flow rate as the mud solidifies. In addition, mud may accumulate within the hole forming a barrier lining that severely limits the potential flow rate in the productive formation or creates a cement-like material if exposed to alkaline solids. Addition of special materials to the mud may solve these problems, but careful selection of these additives is required to avoid other consequences such as mud disposal problems due to additives with toxic heavy metal ions, induced voltage due to the addition of chemicals that could impede effective logging, and cost increases (Ref. 38). 
Another comon problem in drilling is lost circulation. The drilling fluid after passing through the bit escapes into the fractured geological formation. To control circulation losses, either cement or casing is introduced at the appropriate depth, or organic materials are introduced into the appropriate part of the hole. Packing materials, as used in oil and gas drilling, are not entirely satisfactory for geothermal environments. Control methods must be capable of surviving in the geothermal environment, must be easily removed for production and have no residue to plug the formation (Ref.38).

\section{4. - Materials}

Although there are many similarities of environment in oil-gas and geothermal wells, potential geothermal holes fresent a much wider spectrum of variation in the environment, for example, high temperature, presence of hydrogen sulfide, high chloride contents and broad range of $\mathrm{pH}$ in these environments. Screening of different available materials and developing new cements, elastomeric materials, metalic and non-metalic materials to be used for well drilling, well control and completion are needed to make the utilization of geothermal resources more economical.

Development of improved high temperature cementing materials for geothermal wells with good bonding and compressive strength, light weight, stability, compatibility with drilling mud and noncorrosive to steel well casing characteristics is needed. This is an ongoing research at many laboratories (Ref. 39, 40). Cement whose hardness approaches that of the local rock is needed to form a base for starting directional drilling. Cement hardness limits have created problems for attempted directional orilling at Roosevelt and Mono (Ref, 38). 
Temperature-induced decomposition of elastomers as well as difficulties in bonding it to steel, poor lifetime in an abrasive environment and embrittlement on exposure to $\mathrm{H}_{2} \mathrm{~S}$ are limitations on the performance of present drilling equipment. Producing suitable elastomers or finding alternative materials and designs need to be investigated. Research on development of elastomers is carried by L'Garde Inc. (Ref. 41).

Durability of steel can be related to the site specific incidence of $\mathrm{H}_{2} \mathrm{~S}$. Its effects are embrittlement and corrosion. More appropriate steels will improve the lifetime and performance of a number of important drilling tools. For materials research from co-rosion point of view in geothermal environment refer to (Ref 42 ).

Development of durable packers and improvement in the quality of drill pipe for long life and higher reliability are other attractive goals. The lifetime of drill pipe is limited, particularly in cases where air drilling is used, for example, The Geysers (Ref. 38).

Blow-outs and well-bore collapse are also major problems in drilling vells. Both blow-out preventers and the cement which might be used for casing the well are porr performers in a high temperature environment. Hence well control methods adequate for geothermal circumstances need to be improved for safety and cost reasons. The liklihood of well collapse is site-specific and can be expected in sedimentary areas like the Imperial Valley (Ref. 38).

\section{5 - Well Looging and Instrumentation}

The techniques for assessing the reservoir potential or providing a basis for decision making for field development are similar to those already developed to $\log$ potential oil producing sites. The high temperature 
caustic hostile environment combined with the different geothermal formations and other reservoir parameters associated with geothermal wells has placed severe limitations on the use of existing petrophysical well logging techniques and tools in geothermal systems. Research and development needs for well logging techniques, tools and components include development of new and improved logging tools and associated equipment, development of specialized facilities, simulation techniques and interpretation methods for the measurement of temperature, pressure, wellbore flow rate, permeability, hydrochemical data, pososity, etc. Feasibility studies for the determination of the formation temperature and downhole fluid flow rates by applying nuclear techniques performed by IRT Corporation are examples of research activities in this area (Ref. 43,44). For other research activities in the area of well logging and instrumentation see (Ref. 45-47).

3. Power plant

Typically, three schemes or combinations are considered for the utiliza-. tion of liquid dominated resources. The most considered concept is the flash system where the geothermal water is flashed in one or more stages and the vaporized portion of the fluid travels through a steam turbine. The second major scheme is the binary cycle. In this concept, a secondary working fluid exchanges heat with the geothermal $l$ iquid and the former vaporizes. The secondary fluid then flows through a typical Rankine cycle. The third scheme called the "Total Flow Concept" (TFC) has been proposed by the workers at Lawrence Livermore Laboratory. In this scheme, a turbine that can expand a two-phase mixture of water and steam is employed. The choice for the appropriate system for a geothermal site is to some extent 
site-specific and selection of the optimum system for each prospect must be studied. Flash system should be compared with binary system. Performance of different organic fluids ought to be investigated for the binary cycle and the possibility of total flow concept should be considered. Examples of such studies are the comparison of the performance and cost of power cycles for Niland and East Mesa goethermal sites (Ref. 48) or the research carried by University of Oklahoma to develop a computer simulation program for detailed evaluation of binary cycles (Ref. 49). Other important and major research areas in geothermal power plants are as follows:

\section{1 - Heat Exchangers}

In the binary cycle systems the geothermal fluid exchanges heat with the binary fluid in a heat exchanger. Most of the binary fluids with the desirable thermodynamic properties have poor thermal transport properties. Thus, the use of conventional heat exchangers would require large surface areas and hence very high costs. Further difficulties are encountered due to the corrosive nature of the brine and scaling problems accompanied with high salinity brines. Approaches to this problem include development of direct contact heat exchangers where the working fluid is directly brought in contact with the geothermal brine (Ref. 50,51,56). Another approach to the problem is the liquid-fluidized-bed heat exchangers with the fouling fluid (geothermal brine) passing through the shell side. The geothermal brine passes through a bed of particles such as sand, which surrounds the tube bundle. The fluidized particles scrub the tube surface, keeping them free of scale and increasing heat transfer rates (Ref. 52,53 ).

\section{2 - Turbines}

Turbine is one of the expensive pieces of equipment included in a power 
plant. Although steam turbines have been developed and used for a long time, development work tailored to the particular steam conditions of a geothermal site could increase the turbine efficiency and reduce costs. The blades of geothermal steam turbines are subject to silica deposition, hydrogen embrittlement, corrosion and moisture erosion. As a result, turbine downtime is excessive. Metalurgical research and development of turbine blade materials capable of withstanding the damaging effects of geothermal steam could lead to reductions in plant maintenance costs. Large hydrocarbon turbines for binary processes are not currently in commercial use and need to be developed to handle their special problems. The concept of two-phase expanders which was developed by Lawrence Livermore Laboratory needs research and development (Ref. 54). The Total Flow Concept seems, at least thermodynamically, to be suitable for obtaining higher efficiency.

\section{3 - Other Research Programs}

Corrosion and erosion of pump impellers, bearings and seals, and also. of valves used to control flows of geothermal brines, causes shutdowns and hence decreasing overall plant availability and adding to maintenance costs. It is recommended that corrosion and erosion tests be conducted with candidate nonferrous and nonmetallic materials and with brines that contain varying levels of $\mathrm{H}_{2} \mathrm{~S}, \mathrm{CO}_{2}$, chlorides and sand.

Scaling is another problem which causes freezing of valves and plugging the pipes etc., resulting in frequent plant sliutdowns. There are several scale control techniques such as acidification or addition of different scale control additives. These, however, must be field tested using different 
brines to select appropriate scale control method for each particular plant.

Hydrogen sulfide contained in appreciable amounts in most geothermal brines presents a corrosion problem as well as an environmental problem. A number of commercial processes are available for hydrogen sulfide removal. These processes require substantial capital investment and hence research is needed to improve these processes or develop new concepts. An example of such activity is discussed in Ref. 55 .

In brine reinjection, scale buildup in the injection pumps and discharge lines and reduction of the permeability of the receiving reservoir or clogging the pores of the formation canbe one of the most serious risk areas. Therefore, research is needed to study different procedures such as use of settling ponds, reactor clarifier, test filters, hydrocyclones and observe their effect on composition of suspended matter and the plugging factor. (Ref. 57). 


\section{E. Data and Information Sources}

There are a number of valuable generally available assessments of geothermal power both under way and completed. These are either regional assessments and forecasts, or national assessments. Most are bound volumes and quickly out of date.

The sources containing information of value to geothermal energy include databases, pericdicals and research laboratories. Selected sources for sitespecific data are the following:

Assessment of Geothermal Resources of the United States - 1975 (Circ. 726)

is valuable, authoritative and provides comprehensive reference data, including geology, chemistry and wells, which is widely used for site evaluations. The data for a large number of prospects is available via the GEOTHERM database. However, data, for example, on scaling, corrosion and institutional factors are not readily obtained from the report. An update was published in 1979 as circ. 790.

Site-Specific Analys is of Geothermal Development issued in three volumes by Mitre-Mitrek under contract to DOE/DGE is a comprehensive work covering scenarios of geothermal power production in the United States. With minor modifications, the projections for 37 major prospects are included in the second annual report of the Interagency Geothermal Coordinating Council. The forecasts of power on-line utilize data that is inferred or default values as well as measured values.

Geothermal Energy Prospects for the Next 50 Years was prepared by the Electric Power Research Institute. It includes calculated hydrothermal electricity potential in the U.S. and over 20 other nations to the years 1985. 2000 and 2020. Calculations are based in part on site-independent data such as a uniform temperature gradient, and heat capacity. 
Geotherrial Handbook was prepared by the U.S. Fish and Wildlife Service. It contains detailed information and data on geothermal sites in the western U.S., including location, development status through January 1976, and projected drilling to 1977. Valuable data is included on environmental aspects of geothermal exploration and power production.

Proceedings, First Geopressured Geothermal Energy Conference contains detailed and comprehensive information covering the origin, resource assessment, reservoir research and technology, utilization and legal and environmental aspects of geopressured systems. Newer information is available in proceedings of second and third conferences.

Analysis of Requirements for Accelerating the Development of Geothermal Energy Resources in California published in 1977 summarizes resource potential estimates for major California prospects. A scenario for power production to the year $: 020$ is given, including the current status of each prospect. This work and two preceding publications provide extensive data on geothermal areas in California.

Geothemal Energy, Research, Development and Demonstration Program, Second Annual Report, April 1978, sumnarizes the current status of geothermal energy power potential and includes data on well drilling, resource characteristics, ard a development scenario. 
University of Utah Research Institute provides copies of over 20 publications dealing with geothermal developments in Utah and other areas such as Coso Hot Springs, Calif. Contact:

University of Utah Research Institute Earth Science Laboratory 391 Shipeta Way, Suite A

Salt Lake City, UT 84108

Tel. (801) $581-5283$

Nevada Bureau of Mines and Geology has available comprehensive . information on geothermal activities in Nevada. Their publication Report 21 includes a summary of drilling, which has been updated to 1977. A map showing the location of thermal waters and wells of Nevada is available. Information is obtained from:

Nevada Bureau of Mines and Geology

Mackay School of Mines

University of Nevada, Reno

Reno, NV 89507

Tel. (702) 784-6691

The California Division of 011 and Gas (DOG) is lead agency for all geothermal exploratory projects on state and private lands in California. DOG provides maps of geothermal areas to include locations of drillholes, and it publishes weekly summaries of map revision and notices to drill, rework and abandon wells. Besides the rain office in Sacramento, field offices are maintained in Santa Rosa and Long Beach in California. Contact:

California Division of 0 il and Gas

1416 Ninth St., Room 1316-35

Sacramento, CA 95814

Tel. (916) 445-9686

The National Geothermal Information Resource (GRID) was established in 1974 at the Lawrence Berkeley Laboratory with the objective to compile and disseminate critically evaluated data for geothennal energy utilization. 
The data includes both the basic properties of aqueous solutions to high temperatures, and site-specific information for power production and direct utilization. Contact:

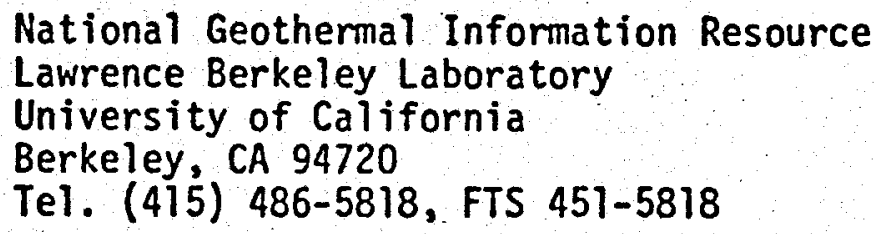

GEOTHERM contains site-specific data on geothermal areas in the United States covering thermal water, geology and reservoir properties. Data covered include the following: locality, surface description, heat flow, temperature, chemical analysis, well flow and temperature. The output is available as a computer printout. Contact:

\section{GEOTHERM}

U.S. Geological Survey

345 Middlefield Road

Menlo Park, CA 94025

Tet. (475) $467-2906$

The Geopressured Geothermal Information Group is establishing a bibliographic database on geopressured systems along with a well-log database. containing digitized well logs for geopressured areas. Information is obtained from:

Geopressured Geothermal Information Grouf University of Texas

Austin, TX

Tel.

Technical Information Center provides comprehensive bibliographies on all major aspects of geothermal energy utilization, both United States and foreign. The material is taken from worldwide journals, reports and other publications. Direct inquiries to:

Technical Information Center

P.0. Box 62

Oak Ridge, TN 37830

Tel. (615) 483-8611 
Conservation Division provides data on leasing of geothermal areas in the United States as a computer print-out. Both competitive and noncompetitive leases are included. Contact:

Office of Area Geothermal Supervisor

Conservation Division

U.S. Geological Survey

345 Middlefield Road

Menlo Park, CA 94025

Tel. (415) $467-2884$

Periodic Publications

Energy Research Abstracts (ERA) is published by the U.S. Department of Energy, Technical Information Center. The ERA is printed twice monthly, and consists of abstracts and indexes of all scientific and technical reports, journal articles, conference papers and other material originated by DOE or DOE contractors. Subscriptions to ERA are $\$ 184$ per year for domestic subscribers and $\$ 230$ per year for foreign subscribers. Subscriptions are obtained from:

Superintendent of Documents

U.S. Goverrment Printing Office

Washington, D.C. 20402

Geothermal Hot Line includes information on drilling, plant construction and lease sales in the Hestern United States. Free subscriptions are obtained from:

Geothermal Hot Line

California Division of 0 il \& Gas

1416 Ninth St., Room 1316-35

Sacramento, CA 95814 
Geothermal Energy is published monthly and contains articles covering major aspects of geothermal utilization. Subscriptions are $\$ 50$ per year for the U.S.:

Circulation Department Geotherma1 Energy 18014 Sherman Way, Suite 169

Reseda, CA 91335

Geothermal Horld Directory contains selected articles dealing with all aspects of geothermal energy including technical, organizational and planning, and a directory of organizations. It is issued annually:

Geothermal World Corporation

18014 Sherman Way

Reseda, CA 91335

Geothermics is a technical publication consisting of engineering and scientific articies on the exploration, environmental and utilization of geothermal energy, including basic data and site-specific data. Subscriptions are obtained from:

Pergamon Press Inc.

Fairview Park

Elmsford, NY 10523

- Geothermal Resources Council Bulletin consists of current information on plant construction, leasing and regulations.

Geothermal Resources Council

P.0. Box 1033

Davis, CA 95616

The Geyser contains information on leasing, plant construction and regulations:

The Geyser

ก.O. Q0. ?525

Beverly Hills, CA 90213 
Munger 0ilogram contains comprehensive data on all drilling in California, Alaska, Arizona, Nevada and the West Coast, including geothermal drilling.

Munger 0 il Information Service, Inc. 9800 South Sepulveda Blvd. Los Angeles, CA 90045

Petroleum Information, National Geothermal Report is published weekly and provides new locations, completions and drilling progress. An editorial section covers other information such as background on discoveries, proposed exploration, and technological developments. Petroleum information also publishes monthly geothermal Completion Cards which are a permanent record of geothermal well completion data. Annual subscription to the weekly National Geothermal Report is $\$ 420.00$ and annual geothermal Completion Cards are $\$ 120.00$ a year.

Petroleum Information Corporation

P.0. Box 2612

Denver, CO 80201

Weekly Summary of notices to.drill, rework and abandon wells, and map revisions for well locations is available for all wells in California, including geothermal.

California Division of $0 i 1$ and Gas

1416 Ninth St., Room 1316-35

Sacramento, CA 95814

Organizations

U.S. Fish and Wildlife Service (FWS) was established in 1974 within the Department of Interior. The FWS predecessor organizations include the Bureau of Fisheries, established 1871, and the Bureau of Biological Survey, 
established in 1885. The Fish and Wildlife Service has 7 regional offices throughout the United States. The geothermal interest of FWS is environmental aspects of land and water; it is one of the agencies with responsibility for environmental assessment. For information:

U.S. Fish and Wildlife Service Department of Interior Washington, D.C. 20240

U.S. Geological Survey (USGS) was established by the act of March 3, 1879 for the classification of public lands and the examination of the geological structure, mineral resources, and products of the national domain; and, in 1962 to include those outside the national domain.

Area Geothermal Supervisor

U.S. Geological Survey

345 Middlefield Road

Menlo Park, CA 94025

Department of Energy (DOE) was established August 4, 1977; DOE provides the framework for a comprehensive national energy plan to include research and development of energy technology, energy conservation and regulation of energy production and use. For geothermal energy, the predecessor agencies were the Atomic Energy Commission and Energy Research and Development Administration. Contact:

U.S. Department of Energy

Division of Geothermal Resources

Washington, D.C. 20545

Bureau of Land Management (BLM) was esta!jlished in 1946 with responsibility for total management of 450 million acres of public lands, to include mineral resources. It is within the Department of Interior. 
The BLM supervises lease sales for geothermal lands. Contact:

Bureau of Land Management

U.S. Department of Interior

Hashington, D.C. 20240

Bureau of Reclamation (BuRec) was established in 1923 to locate, construct, operate and maintain works for the development and storage of waters in the western United States, as related to reclamation of arid and semiarid lands. The BuRec has been active in desalination efforts at the East Mesa site in California. Contact:

Bureau of Reclamation

Department of Interior

Washington, D.C. 20240

Forest Service (FS) was created February 1, 1905 to manage the forest reserves of the U.S. The FS is involved in environmental aspects of geothermal energy. Contact:

Forest Service

Department of Agriculture

P.0. Box 2417

Washington, D.C. 20013

Electric Power Research Institute (EPRI) was founded in 1972 to expand electric energy research and development under the voluntary sponsorship of the nation's utility industry; to develop coordinated advanced technology programs for improving electric power production, transmission, distribution and utilization in an environmentally acceptable manner. Primary areas of research are: nuclear power, fossil fuel and advanced systems, electrical systems and energy analys is and environment. Maintains library. Publishes monthly journal, also publishes reports from 
research projects. Contact:

Electric Power Research Institute

P.0. Box 10412

Palo Alto, CA 94303

National Electric Reliability Council (NERC) was founded in 1968 to periodically review regional and inter-regional activities on reliability and adequacy, and to act as an information exchange media relating to power supply in North America. Address inquiries to:

National Electric Reliability Council

Research Park, Terhune Rd.

Princeton, NJ 08540 
F. Summary and Conclusion

Accurate assessment of individual sites for power production or direct utilization and forecasts for utilization of the resources in the western United States require reliable data.

Geothermal power plants are currently only in The Geysers region in California where the 1979 power output is 608 MWe from 12 units. Construction and plans include over 10 additional plants in California, New Mexico, Idaho, Utah, Nevada and Hawaij (Ref. $7,12,13$ ). See Table 2.

Tables 3 and 4 show drilling activities in California during 1978 and 1979. For drilling activities in California in 1977 refer to (Ref. 59), and for years prior to 1977, see (Ref. 19, 60). Table 5 gives drilling data. for the state of Nevada. Leasing data for the state of California is presented in Table 6 and 7. The increase in geothermal activities in California and other western states is obvious, and hence the need for accurate data.

This geothermal databook provides up-to-date reference data useful in assessing geothermal areas for their potential to produce electric power. A summary of current site-specific data for the western United States is given in Appendix I. The site-specific data for 21 geothermal prospects presently stored on the Energy Conversion (ENCON) file is presented in Appendix 11. And finally, the exploration and development of geothermal energy requires data to include diverse areas as location of roads and railways, existing land use, availability of water, proximity to transmission lines and annual rainfall. Appendix III consists of maps of California and Nevada containing this information. 
TABLE 2. - POUER PLANT COISTRUCTION IN THE WESTEPN UNITED STATES (REF. $11,62-77$ )

Geothermal Area

Developer and Constructor

MWe

On-Line

California

The Geysers

Unit 12

Unit 13

Unit 14

Unit 15

Units 16, 17

Units 18,19

Units 20,21

Units 22,23

Units 24,25

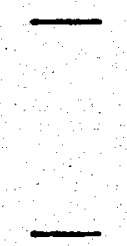

Bottle Rock

South Geysers
Pacific Gas \& Electric Co., Union-Mayma-Thermal

Pacific Gas \& Electric Co., Aminoil USA, General Electric Turbine

Pacific Gas \& Electric Co., Union-Magma-Thermal, Toshiba Turbine

Pacific Gas \& Electric Co., General Electric Co., Thermogenics

Pacific Gas \& Electric Co., Aminoil USA, Union-MagmaThermal, Toshiba

Pacific Gas \& Electric Co., Aminoil USA, Union-MagmaThermal, Toshiba

Pacific Gas \& Electric Co.

Pacific Gas \& Electric Co.

Pacific Gas \& Electric Co.

Northern California Power

Agency, Shell Oil Co., Plumas-Sierra Rural, Electric Cooperative

Northern California Power Agency, Resource Funding Limited

California Division of Water Resources

DWR South Geysers

SMUD Ho. 1

SMUD No. 2

DWR Newfield

Hot Water No. 1
106

135

1980

110

March 1980

55

June 1979

110,110

1981 (16)

1982 (17)

110,110

1982 (18)

1983 (19)

110,110

1984

110,110

$1985,1986$.

110,110

1987, 1988

55,55

Oct. 1981 ( 55 MHe)

Mar. 1982 (55 Mle)

33,33

Oct. 1983 (33 MUle) Jan. 1984 (33 MHe)

55

1983

55

110

110

55

50
1984

1985

1986

1985

1986 
TABLE 2. (continued)

Geothermal Area

Hot Water No. 2,3

100

Hot Uater No. 4, 5, $6 \quad 150$

Hot Water No. $7,8,9,10$

200

1988

Hot Water No. 11, 12, 13, 14,200

1989

1990

Brawley

Union Dil Co., Southern

10

mid-1980

California Edison Co.

Cul Venture

50

Union 0il Co., Southern

10

early-1980

Salton Sea

Cal ifornia Edison, Southern

Pacific Land Co.

Magma Power Co., San Diego

50

1982

Gas \& Electric Co., Morrison

Knudsen Co.

East Mesa

Republic Geothermal, Inc., San Diego Gas \& Electric Co., Ralph M. Parsons Co., General Electric Co.

Magma Power Co., Imperial

June 1979

Irrigation District

48 net

1981

10 (initial) June 1980

Chevron Resources Co.,

Southern California Edison Co.

50

1982

California Department of

55

Hater Resources, Geo-Produrts

Corp.

Kestmorland

Republic Geothermal, Inc.,

1983 MAPCO

50

Jan. 1982

Baca Location No. 1

Union Oil Co., Public Service

50

Company of New Mexico, U.S.

Department of Energy

Idaho

Raft River

Idaho National Engineering

early-1980

Hawaii

Puna

Hawaii Electric Co., State of Hawai 
TABLE 2. (continued)

Geothermal Area

Utah

Roosevelt

Roosevelt

Nevada

To be selected

\section{Desert Peak \\ (Brady-Hazen)}

Phillips Petroleum Co.,

early-1984

Thermal Power Co., Utah

Power \& Light,

ANAX, O'Brien Resources,

VTN Consolidated, Utah Power

\& Light, Natomas

Phillips Petroleum Co., Southern Union Production

20

1983

Co., Sierra Pacific Power

Co., Stone \& Webster

Engineering

Sacramento Municipal Utility

District, Eugene Water \& Electric Board, Sierra

Pacific Power
20

(may be unitized)

On-Line 
TABLE 3. - GEOTHEPMAL DRILLING IN CALIFORNIA IN 1979 (Ref. 16,17 )

Geothermal Area

The Geysers

Brawley/Imperial

County

Salton Sea/Imperial

County
Operator

Aminoil USA Inc.

(CA956) $37 A-34$

(CA1862) $57-27$

D\& V3

Geothermal Kinetics, Inc. "Rorabaugh" 2

McCulloch Geothermal

Corp.

Coleman 1-5

Coleman 1-6

Natomas Co.

Davies-State 5206-1 Atlantic 0il Co.

Union Dil Co.

DX State 4596-43

"Cobb Mountain

Hunting Club" 7

DX State 4596-40

DX State 4596-44

McCulloch Geothermal

Corp.

Mercer 2-28 (I)

Union Oil Co.

Veysey 9

Union Oil Co.

I.I.D. 5 (E)

I.I.D. 6

"Sinclair" 13 (E)

McCulloch Geothermal

Corp.

Hot Mineral 1-15 (E) Republic Drilling Co. Hot Mineral 2-15 (E)

Imperial Magma

IW 5 (I)
Drilling Rig.

Montgomery Orilling

Montgomery Drilling

Montgomery Drilling

Atlantic 0il

Monterey Drilling

Monterey Drilling

Loffland Bros.

Loffland Bros.

Loffland Bros.

Loffland Bros.

Republic Drilling Co.

Loffland Bros.

Loffland Bros.

Loffland Bros.

Loffland Bros.

spud $1 / 30 / 79$ completed $1 / 30 / 79$ completed $2 / 18 / 79$ completed Mar. 1979

Coastal Drilling Co. spud 2/8/79, rel. rig $4 / 23 / 79$ spud $2 / 8 / 79$

spud $1 / 4 / 79$

spud $1 / 1 / 79$

spud $1 / 27 / 79$, completed $3 / 28 / 79$ spud $3 / 20 / 79$ spud $3 / 6 / 79$ spud 1/2/79, spud 1/29/79,

spud $4 / 9 / 79$

spud 2/19/79,

spud $1 / 27 / 79$, completed spud $2 / 12 / 79$, rel. rig $2 / 18 / 79$ 
TABLE 4. - GEOTHERMAL DRILLING IN CALIFORNIA IN 1978 (Ref, 16,18)

Geothermal Area

Brawley/Imperial

County.
Phillips Petroleum Co. Borax Lake 7-T(E)(0)

Borax Lake/Lake County

Clear Lake/Lake County

East Mesa/Imperial

Ceunty

Magma Power Co.

7, $44 A-7$

\author{
Operator \\ Chevron USA Inc. \\ Brandt 1 (E) \\ Orita $(-131(0)$ \\ McCulloch Geothermal \\ Corp. \\ Francisco 2-5 (E) \\ Phillips Petroleum \\ East Brawley Strat \\ Test $I$ (E) \\ East Brawley Strat \\ Test IA (E) (0) \\ East Brawley Strat \\ Test 2 (0) \\ East Brawley Strat \\ Test $3(0)$ \\ Union 0 il Co. \\ Slater 1 (E) \\ Veysey 7 (E) (I) \\ Veysey 8 (P)
}

Mercer 1-28 (E) Republic Drilling

Hunnicutt \& Camp

Orilling

Peter Bawden Drilling spud $8 / 7 / 78$

Co.

Peter Bawden Drilling spud Mar. 78

Co.

Comments

spud $7 / 11 / 78$, completed

Drillina Rig

Drilling

Dixie Drilling

Peter Bawden Drilling

Peter Bawden Drilling

Peter Bawden Drilling originally Cammay Drilling, change to Montgomery Drilling

Atlantic 0il co.

spud $9 / 3 / 78$, suspended $12 / 29 / 78$

$7,44 B-7$

7, $46 \mathrm{~A}-7$ (I)

$7,46 B-7$ (I)

$7,48 A-7$ (P)
Coastal Drilling Co. spud $6 / 3 / 78$

Coastal Drilling Co. spud $7 / 30 / 78$

Coastal Drilling Co. completed Sept. 78

Coastal Drilling Co. completed 11/8/78

Coastal Drilling Co. spud 10/30/78 spud $11 / 5 / 78$ completec completed $8 / 25 / 78$ spud $8 / 25 / 78$.

spud $2 / 76 / 78$, $11 / 22 / 78$ idle 
TABLE 4. (continued)

Geothermal Area

The Geysers
Operator

Republic Geothermal

Inc.

East Mesa 58-30

Aminoil USA Inc. (CA956) 37-34

(CA956) 73-34

(CA958) $56 \mathrm{~A}-34$

Thorne 7

Aidlin $3(s)$

McCulloch Geothermal

Corp.

Newfield 1-33 (E)

Thermogenics Inc.

GRI-Rorabaugh 1

GRI-Rorabaugh 2

Rorabaugh A-9

Rorabaugh A-11

Klau Mines-K- K-1A(S)

Union 0il Co.

Angeli 1 (E)(S).

Occidental Federal

1

"Cobb Mounta in ..

Hunting Club" 6

LF State 4597,21

(S)

Hunnicut \& Camp

Drilling

Hoover Drilling

Hoover Drilling

Hoover Drilling

Big " 0 " Drilling

Big "O" Drilling

Loffland Bros.

Loffland Bros.

Loffland Bros.

LF State 4597,23

LF State 4597,24

DX State 4596-19

DX State 4596-38

Ottoboni State

4596-25 (P)

Sulphur Bank 25

Sulphur Bank 26

Sulphur Bank 27

Shell Oil Co.

U.S. Geotherma?

$33 A-4$

U.S. Geothermal

43-4 (E) (A)

Loffland Bros.
Atlantic Oil Co.
Loffland Bros.

Comments

spud $7 / 9 / 78$

spud $11 / 15 / 78$, Rel. rig $1 / 2 / 78$

spud $2 / 11 / 78$ spud 6/3/78, Rel. rig 9/16/78 completed spud $4 / 1 / 78$, suspended $7 / 24 / 78$

spud $11 / 27 / 78$

spud $5 / 8 / 78$,completed spud $1 / 20 / 78$, suspended $5 / 12 / 78$

spud $9 / 2 / 78$, suspended $12 / 30 / 78$

spud $10 / 4 / 78$, completed $1 / 30 / 79$

spud $7 / 18 / 78$

spud $1 / 21 / 78$, suspended $2 / 9 / 78$ spud $2 / 5 / 78$ completed $8 / 31 / 78$ completed Apr. 78 completed June 78

spud $5 / 30 / 78$ conipleted $2 / 23 / 78$ spud $2 / 21 / 78$, completed Apr. 78 spud $3 / 28 / 78$, abandoned $6 / 24 / 78$ 


\section{TABLE 4. (continued)}

Geothermal Area

Operator

U.S. Geothermal

69-2 (E) (A)

Middletown/Napa County Amax Exploration Inc. Amax 1

Salton Sea/Imperial County.
Union 0 il Co.

Sinclair $15(P) \quad$ Loffland Bros.
Drilling Rig

Atlantic 0il Co.

Montgomery Drilling
Comments

spud $6 / 30 / 78$, abandoned $8 / 23 / 78$

spud $8 / 4 / 78$, Rel. rig $11 / 5 / 78$

spud $10 / 22 / 78$, completed $1 / 10 / 79$

$E=\operatorname{exploratory}, P=$ production, $I=$ injection, $S=$ suspended, $A=$ abandoned, $O=$ observation 
TABLE 5. - GEOTHERMAL DRILLING IN NEVADA TO 1977 (Ref. 8,29)

Haximum

Well

Completion Temperature

Operator

Name

Depth, m Date

$\left({ }^{\circ} \mathrm{C}\right)$

CHURCHILL COUNTY

Brady's Hot Springs

Magma Power Co.

Magma Power Co.

Magma Power Co.

Magna Power Co.

Magma Power Co.

Magma Power Co.

Magma Power Co.

Earth Energy Inc.

Earth Energy Inc.

Union Oil Co. of Calif.

Magma Energy Inc.

Magma Energy Inc.

Brady No. 1

Brady No. 2

Brady No. 3

Brady No. 4

Brady No. 5

Brady No. 6

Brady No. 7

R Brady EF.No.1

Brady Pros. No.1

SP-Brady No.1

SP-Brady No.2

SP-Brady No.8

$\begin{array}{cc}213 ? & 1959 ? \\ 73 & 1959 ? \\ 186 & 1961 ? \\ 220 & 1961 ? \\ 181 & 1961 ? \\ 235 & ? \\ 76 & ? \\ 1543 ? & 1964 \\ 536 ? & 1965 ? \\ 2217 & 1974 \\ 1355 & 1975 \\ 1057 & 1975\end{array}$

166

168

1961 ?

?

$?$

964

212

1965?

179

188

Desert Peak Area

Phillips Petroleum Co.

Desert Peak No.29-1

2335

1974

Desert Peak B

1265

1976

208

Phillips Petroleum Co. No.21-1

Desert Peak B

973

1976

199

Soda Lake

No.27-2

Chevron-Phillips

Chevron Resources Co.

Soda Lake No. 1-29

1312

1545

1974

Soda Lake No.44-5

1978

Stillwater

O'Neill Geothermal Inc.

J.I. O'Neill, Jr.-

1291

1964

129

Union 0 i] Co. Reynolds No.1

Union 0 il $\mathrm{Co}$.

Weishaupt No.1

Union OII Co.

Weishaupt No.2

De Braga No.1

1219

1219

1219

$\cdot 1976$

.1977

$\cdot 1977$

Lee Hot Springs

Oxy Geothermal Inc.

Federal No.72-33(K) $\quad 919$

$1978 ?$

DOUGLAS COUNTY

Hally's Hot Springs

U.S. Steel Corp.

Hally's No.1

386

152

1962

1962

83 
TABLE 5, - GEOTHERMAL DRILLING IN NEVADA TO 1977 (cont inued)

Operator $\begin{aligned} & \text { Well } \\ & \text { Name }\end{aligned} \quad$ Depth, $m$ Completion Date $\begin{gathered}\text { Maximum } \\ \text { Demperature } \\ \left({ }^{\circ} \mathrm{C}\right)\end{gathered}$

\section{EUREKA COUNTY}

Beowawe Geysers

Magma Power Co.

Magma Power Co.

Vulcan Thermal Power Co.

Vulcan Thermal Power Co.

Vulcan Thermal Power Co.

Vulcan Thermal Power Co.

Vulcan Thermal Power Co.

Vulcan Thermal Power Co.

Sierra Pacific Power Co.

Sierra Pacific Power Co.

Sierra Pacific Power Co.

Sierra Pacific Power Co.

Magma Energy Inc.

Hot Springs Point

(Crescent Valley)

Magma Power Co.

Chevron Oil Co.

HUMBOLDT COUNTY

Hot Springs Ranch

Magma Power Co.

LANDER COUNTY

Beowawe Geysers

Chevron-American Thermal

Resources

Chevron U.S.A. Inc.
Beowawe No. 1

Beowawe No.2

Vulcan No.1

Vulcan No.2

Vulcan No.3

Vulcan No.4

Vulcan No.5

Vulcan No.6

Sierra No.1

Sierra No.2

Sierra No.3

Sierra No.4

Batz No.1
585

218

194

200

243

234

72

146

283

127

625

306

1660

Hot Springs Point No. 1(?)

Hot Springs Point

No.1

125

712
1959 ?

1959 ?

1961

1961

1961

1961

1963?

1963

1964 ?

1964

1965

1964 ?

1975

1965

74

212

208

208

210

139

116

1975
Tipton No.1

936

1974

Ginn No.1-13

Rossi No.21-19

(Beowawe No.1)
1974

1976

\section{LYON COUNTY}

Hazen (Ferniey)

Magma Poiver Co.

Magnia Power Co.

Hazen No.1 (?)

229

Hazen No.2 (?)

$91 ?$

1962

1962 
TABLE 5. - GEOTHERMAL DRILLING IN NEVADA TO 1977 (continued)

\begin{tabular}{|c|c|c|c|c|}
\hline Operator & $\begin{array}{l}\text { Hell } \\
\text { Name }\end{array}$ & Depth, m & $\begin{array}{c}\text { Completion } \\
\text { Date }\end{array}$ & $\begin{array}{l}\text { Maximum } \\
\text { Temperature } \\
\left({ }^{\circ} \mathrm{C}\right)\end{array}$ \\
\hline \multicolumn{5}{|c|}{ Hazen (Fernley) - continued } \\
\hline $\begin{array}{l}\text { Magma Power Co. } \\
\text { Magma Energy Inc. }\end{array}$ & $\begin{array}{l}\text { Hazen No.3 (?) } \\
\text { Fernley No.I }\end{array}$ & $\begin{array}{l}91 ? \\
1118\end{array}$ & $\begin{array}{l}1962 \\
1974\end{array}$ & \\
\hline \multicolumn{5}{|l|}{ Kabushka Hot Springs } \\
\hline $\begin{array}{l}\text { Magma Power Co. } \\
\text { Magma Power Co. } \\
\text { Magma Power Co. }\end{array}$ & $\begin{array}{l}\text { Wabushka No.1 } \\
\text { Wabushka No.2 } \\
\text { Wabushka No.3 }\end{array}$ & $\begin{array}{l}149 \\
162 ? \\
678\end{array}$ & $\begin{array}{l}1959 \\
1959 \\
1959\end{array}$ & 108 \\
\hline \multicolumn{5}{|l|}{ Hind's Hot Springs } \\
\hline $\begin{array}{l}\text { U.S. Steel Corp. } \\
\text { U.S. Steel Corp. } \\
\text { U.S. Steel Corp. }\end{array}$ & $\begin{array}{l}\text { Hind's No.1 (?) } \\
\text { Hind's No.2 (?) } \\
\text { Hind's No.3 (?) }\end{array}$ & $?$ & $\begin{array}{l}1962 ? \\
1962 ? \\
1962 ?\end{array}$ & 66 \\
\hline
\end{tabular}

\section{NYE COUNTY}

Darrough Hot Springs

Magma Power Co.

PERSHING COUNTY

Humboldt (Rye Patch)

Phillips Petroleum Co. Union 0 il Co.

Campbell E No.1

Campbe11 No.1
565
$\sim 2012$

2012
1977

1978

HASHOE COUNTY

Ward's Hot Springs (Fly Ranch)

Hestern Geothermal Inc.

Fly Ranch No.1 (?) $305+$

1964

Granite Ranch

Western Geothermal Inc.

(?) Granite Creek

244

$1965 ?$ Ranch 1

San Emidio Desert

Cherron oil Co.

Cosmos No. 1-8

Cherron Oil Co.

Cosmos No. 1-9

1223

1636

1975

1978

The Needles (Pyramid Lake)

Western Geothermal Inc.

Needles No.1

1795

1964

$\sim 116$ 
TABLE 5. - GEOTHERMAL DRILLING IN NEVADA TO 1977 (continued)

$\begin{array}{lccc}\text { Operator } & \text { Well } & \text { Completion Temperature } \\ \text { Date } & \text { Name } & \text { Maximum } \\ \text { ( } \mathrm{C})\end{array}$

The Needles (Pyramid Lake) - continued

Western Geothermal Inc. Needles No.2 (?) 1219.4 1962

Western Geothermal Inc. Needles No.3 (?) 1964

Steamboat Hot Springs

$\begin{array}{llllll}\text { Nevada Thermal Power Co. } & \text { Steamboat No.1 } & 558 & 1954 & \\ \text { Nevada Thermal Power Co. } & \text { Steamboat No.2 } & 294 & 1959 & \\ \text { Nevada Thermal Power Co. } & \text { Steamboat No.3 } & 385 & 1960 ? & 186 \\ \text { Nevada Thermal Power Co. } & \text { Steamboat No.4 } & 158 ? & 1960 & 186 \\ \text { Nevada Thermal Power Co. } & \text { Steamboat No.5 } & 252 & 1961 & 175 \\ \text { Nevada Thermal Power Co. } & \text { Steamboat No.6 } & 218 & 1961 & 179\end{array}$

WHITE PINE COUNTY

Monte Neva Hot Springs

Magma Power Co.

Monte Neva No.1 (?) $123 \quad 1965$

88 
TABLE 6, - GEOTHERMAL LEASES IN CALIFORNIA AS OF DEC. 1978* (Ref. 27,78,79)

Geothermal Area and/or County

East Mesa/Imperial County
Current Lessee Lease No. COAPETITIVE LEASES

Magma Power Co. CA964

CA965

CA968

Republic Geothermal CA966

CA967

CAI903
Lake City-Surprise

Valley/Modoc

Mono Long Valley/ Mono

The Geysers

Wendel Amedee/Lassen

Imperial County

Inyo County
Suporn Energy Corp. CA3064

Geothermal Resources

$\begin{array}{cccc}\text { Int. } & \text { CA961 } & 1815.08 & 3 / 1 / 75 \\ \text { " CA962 } & 1895.21 & " 1 / 77\end{array}$

Shell 0 il Co. CA949

Thermogenics Inc. CA951

Union 0il, Magina Power

,Thermal Power

CA952

"

CA953

CA954

Aninoil USA Inc.

CA956

Aminoil USA and

Occidental Geoth.

CA956A

CA958

Union 0it, Magma Power

,Thermal Power

CA959

CA960

Aminoil USA Inc.

CA1862

Union Oil, Magma Power

Thermal Power

CA1863

Shell Oil Co.

CA4602

CA4603

R.O.Elliott

CA5411

2477.12

1599.63

174.72

251.85

168.90

2395.23

79.95

$8 / 1 / 74$

u

$10 / 1 / 74$

$\mathbf{1 1}$

$8 / 1 / 74$

169.60

223.79

45.00

736.94

625.03

$10 / 1 / 74$

$11 / 1 / 74$

$8 / 1 / 74$.

160.00

1653.15

1203.81

$12 / 1 / 77$

1205.20

$12 / 1 / 78$

NONCOMPETITIVE LEASES

Natomas Co. CAI063

Black, Quirk, Zebal

and VTN Consolidated

Inc.

CA1156

CAII58

Magma Energy Inc. CA2364

2243.33

$7 / 7 / 78$

2122.42

1710.80

761.00

$7 / 1 / 78$

$6 / 1 / 78$

Kerr McGec Chemical CA1065

CA1066

2561.50

$12 / 1 / 76$

2556.00

1760.00

1880.05

2025.73

CA1068

CA1069

(1)

$\begin{array}{lll}* & \text { " } & \text { CA1068 } \\ * & \text { CA1069 }\end{array}$

, 
TABLE 6. - GEOTHERMAL LEASES IN CALIFORNIA AS OF DEC. 1978 (Continued)

Geothermal Area

Current Lessee Lease No. Acerage Date Leased and/or County

Modoc County

NONCOMPETITIVE LEASES(Cont inued)

$\begin{array}{llll}\text { Eason 0il Co. } & \text { CA1305 } & 1280.00 & 9 / 1 / 75 \\ \text { Mobil 0i1 Co. } & \text { CA1140 } & 1037.76 & 11 / 1 / 75 \\ \text { " } & \text { CAI141 } & 873.65 & 11 \\ \text { Supron Energy Corp. } & \text { CA3075 } & 1279.00 & 4 / 1 / 76 \\ \text { " } & \text { CA3076 } & 1824.03 & \end{array}$

San Bernandino County Getty 0 il and

Mono Power
"
"

$$
\begin{aligned}
& \text { CA998 } \\
& \text { CA1026 } \\
& \text { CA2251 } \\
& \text { CA2444 }
\end{aligned}
$$

1640.00

1118.36

1599.88

1120.00

$9 / 1 / 78$

(1)

"

INDIAN LEASES

Modoc County Geothermal Power Corp.

SBLI15

$480.00 \quad 1 / 29 / 74$

Mono County

Getty Oil Co.

SBL74

$120.00 \quad 10 / 5 / 71$

* Additional information on leasing and sale dates beyond Dec.1978 may be obtained from References $(20-26,28)$. 
TABLE 7. - ISSUED FEDERAL LEASES* - CALIFORNIA

AS OF DEC. 5, 1978 (Ref. 27)

\begin{tabular}{|c|c|c|c|c|c|c|c|c|c|}
\hline \multirow{2}{*}{ County } & \multicolumn{2}{|c|}{ Noncompetitive Leases } & \multicolumn{2}{|c|}{ Competitive Leases } & \multicolumn{2}{|c|}{ Indian Leases } & \multicolumn{3}{|c|}{ Total Leases Issued } \\
\hline & $\begin{array}{l}\text { Po. of } \\
\text { Leases }\end{array}$ & Acreage & $\begin{array}{l}\text { No. of } \\
\text { Leases }\end{array}$ & Acreage & $\begin{array}{l}\text { No. of } \\
\text { Leases }\end{array}$ & Acreage & $\begin{array}{l}\text { No. of } \\
\text { Leases }\end{array}$ & Acreage & \begin{tabular}{|l|} 
Indian \\
Acreage
\end{tabular} \\
\hline Imperial & 4 & $6,837.55$ & 6 & $11,770.00$ & -1 & - & 10 & $18,607.55$ & -1 \\
\hline Inyo & 5 & $10,783.28$ & - & - & - & - & 5 & $10,783.28$ & - \\
\hline Lassen & - & - & 1 & $1,205.20$ & - & - & 1 & $1,205.20$ & - \\
\hline Kodoc & 5 & $6,294.44$ & 1 & $2,586.46$ & 1 & 480.00 & 7 & $9,360.90$ & 480.00 \\
\hline Mono & - & - & 3 & $5,482.99$ & 1 & 120.00 & 4 & $5,602.99$ & 120.00 \\
\hline San Bernardino & 4 & $5,478.24$ & - & - & - & - & 4 & $5,478.24$ & - \\
\hline $\begin{array}{l}\text { Sonota, Lake } \\
\text { Mendocino }\end{array}$ & - & - & 15 & $12,134.32$ & - & $-:$ & 15 & $12,134.32$ & - \\
\hline TOTAL & 18 & $29,393.51$ & 26 & $33,178.97$ & 2 & 600.00 & 46 & $63,172.48$ & 600.00 \\
\hline
\end{tabular}

*All leases are currently active. 
G. Unit Conversion Factors

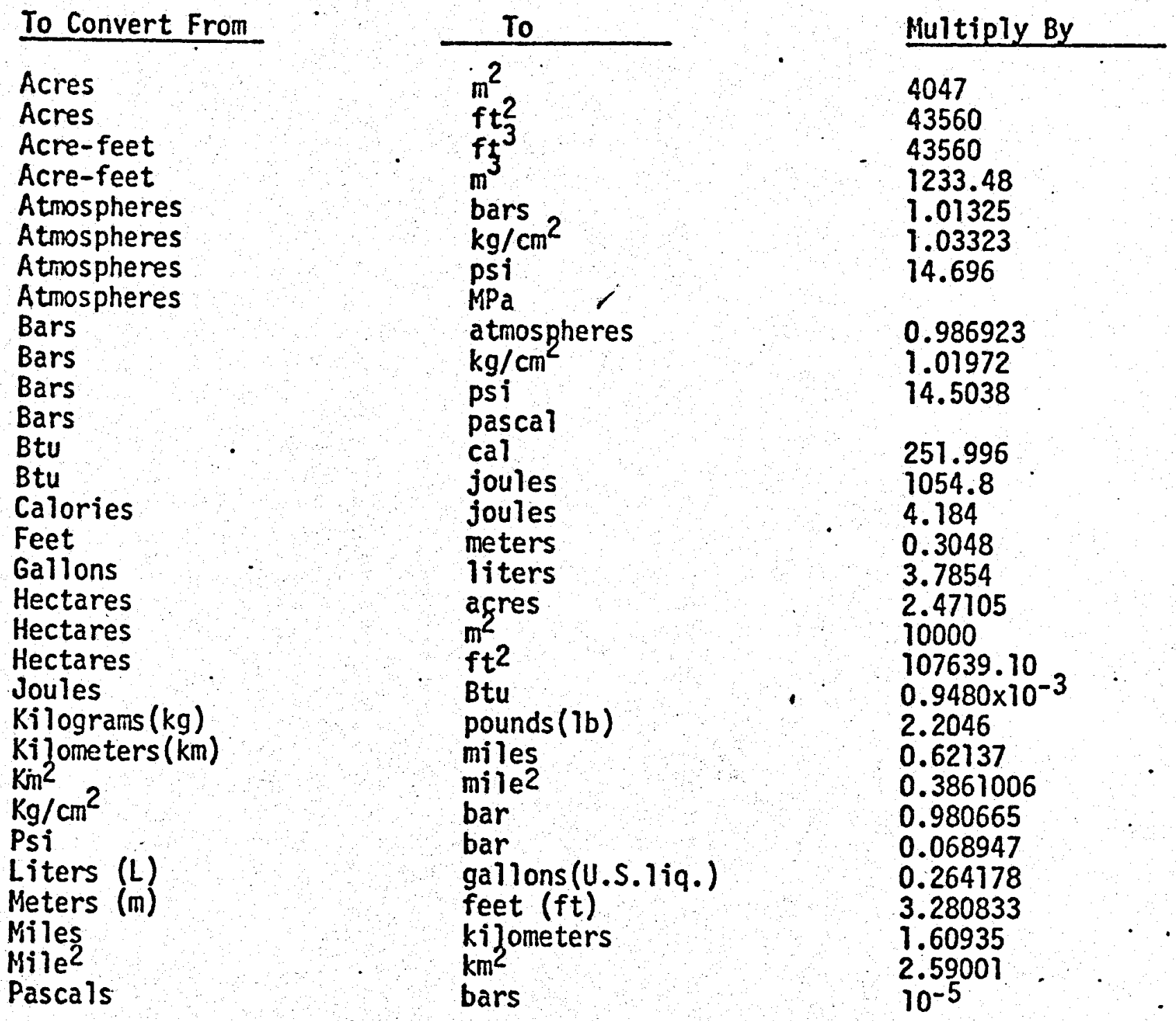


H. References

1. "Geothermal Energy, Rescarch, Development and Demonstration Program", Second Annual Report, DOE/ET-0039/1, IGCC-3, Interagency Geothermal Coordinating Council, April 1978

2. Greider, B., "Econonic Risk of Geothermal Projects", in Proceedings of the Second Geothermal Conference and Workshop, Taos, NM, June 20-23, 1978, P.85, EPRI WS-78-97, October 1978

3. "Geothermal Energy Resources in California: Status Report, Appendix", JPL Document 5040-25, Energy Resources Conservation and Development Commission, Sacramento, CA 1976

4. "Geothermal Handbook - Geothermal Project 1976", NP-21172, Department of the Interior, Fish and Vildlife Service, June 1976

5. Williams, F., Cohen, A., Pfundstein, R., Pond, S., "Site-specific Analys is of Geothermal Development - Data Files of Prospective Sites", Vol. 3, HCP/T4014-01/3, UC-66, February 1978

6. "Cumulative Geothermal Statistical Bid Recap", CY1976-1978, U.S. Department of the Interior, Geological Survey, Menlo Park, 1978

7. DiPippo, R., "Geothermal Power Plants of the United States: A Technical Survey of Existing and Planned Installations", C00-4051-20, Brown University, April 1978

8. Garside, L., "Geothermal Exploration and Development in Nevada Through 1973", Nevada Bureau of Mines and Geology, Report 21, Mackay School of Mines, University of Nevada, Reno, 1974

9. "Geotherm Database", U.S. Geological Survey, Office of Resource Assessment, Mento Park, CA 1979

10. "Proceedings of First Geopressured Geothermal Energy Conference", Dorfman, M.H., and Dellers, R.W., eds., Center for Energy Studies, University of Texas at Austin, Austin, TX, iune 2-4, 1975

11. "Regional Hydrothermal Commercialization Plan", Department of Energy, Division of Geothermal Energy, July 1978

12. Hughes, E.E., "Geothermal Power Plant Commitments in California", Proceedings of the Second Geothermal Conference and Workshop, Taos, NM, June 20-23, 1978, P.61, EPRI WS-78-97, October 1978 
13. Kruger, P., "Utility Estimates of Geothermal Electricity Generating Capacity", Geothermal Resources Council Transactions, Vol. 2, Sec. 2, P.379, 1978

14. "Geothermal Ventures Planned for the Western U.S.", Geothermal Hot Line, $\underline{8}$ (4), P.2 (1978)

15. "The Geyser", $\underline{5}(8)$, P.1 (1978)

16. "Munger 0ilogram", Munger 0il Information Service, Inc., Los Angeles, CA, (1979)

17. "Petroleum Information", March 2, 1979

18. "Munger 0ilogram", Munger 0 il Information Service, Inc., Los Angeles, CA, (1978)

19. Fredrickson, C.D., "Analysis of requirements for Accelerating the Development of Geothermal Energy Resources in California", Jet Propulsion Laboratory, JPL publication 77-63, November 1977

20. "Geothermal Resources Lease Sale, The Geysers-Calistoga KGRA", The Geyser, $\underline{5}(5)$, P.1 (1978)

21. "The Geyser", 5 (4), P.3 (1978)

22. "The Geyser", 4 (17), 1978

23. "The Geyser", $\underline{5}$ (7), P.1 (1978)

24. "Geothermal Hot Line", 8 (4), P.6 (1978)

25. "Bulletin Geothermal Resources Counci1", I (5), P.16 (1978)

26. "BLM-California Tentative Geothermal Resources Lease Sale Schedule", The Geyser, 4 (15), P.3 (1978)

27. "Geothermal Applications and Lease Records Systems Format A-7", U.S. Geological Survey, Conservation Division, AGS, Menlo Park, CA, 1978

28. Geothernal Report, 8 (7), P.3, 1979

29. Garside, L, , "Updates and Corrects Table 1 of Nevada Bureau of Mines and Geology Report 21", April 22, 1977 (See Ref. 8)

30. Keller, G.V., "Research on the Physical Properties of Geothermal Reservoir Rocks", Colorado School of Mincs, C00-2908-2, Jan. 1977

31. Keller, G.V., Grose, L.T., Pickett, G.R., "Research on the Physical Properties of Geothermal Reservoir Rock", Colorado School of Mines, C00-2908-3, March 1978 
32. Maurer, H.C., "Patent Research and Review on Roller-Bit Bearings, Seals and Lubrication Systems", Maurer Engineering, Inc., Houston, Texas, TID-28698, Oct. 1975

33. Barker, L.M., Green, S.J., Maurer, H.C., "Semi-Annual Report on the Project to Design and Experimentally Test an Improved Geothermal Drill Bit", Terra Tek, Inc., Salt Lake City, Utah, TID-28704, Jan. 1976

34. Hibbs, L.E., Jr. and Flom, D.G., "Geothermal Compax ${ }^{R}$ Orill Bit Development", General Electric Company, Corporate Research and Development, TID-28702, Dec. 1976

35. Hendrickson, R.R., Barker, L.M., Green, S.J. and Wingenried, R.W., "Support Research for Development of Improved Geothermal Drill Bits", Terra Tek, Inc., TID-28320, June 1977

36. Maurer, W.C., "Program to Develop Improved Downhole Drilling Motors", Terra Tek, Inc., Salt Lake City, Utah, TID-28687, Nov. 1976

37. Nielsen, R.R., Black, A.D., Green. S.J., Matson, L.W., Maurer, W.C., Ninon, J.D. and Wilson, J.G., "Program to Develop Improved Downhole Drilling Motors", Terra Tek, Inc. and Maurer Engineering, Inc., TID-28686, Mar. 1977

38. "Prospects for Improvement in Geothermal Well Technology and Their Expected Benefits", The Mitre Corporation, HCP/T4014-04, UC-66C, June 1978

39. Kukacka, L.E., Fontana, J., Sugama, T., Rockett, T.J., Kalyoncu, R.S., Curtice, D.K., Fuller, E.R., Zeldin, A., Carciello, N., Reams, W., Kalousek, C.L., Simpson, B.E. and Roy, D.M., "Cementing of Geothermal Wells", Progress Report No. 8, Jan-Mar. 1978, Brookhaven National Laboratory, ENL-50850, July 1978

40. Eilers, L.H., Free, D.L., Nelson, E.B., Simpson, B.E., Spangle, L.B. and Williams, J.F., "Development of Geothermal Well Completions Systems", Dow Chemical Company, Dowell Division, C00/4190-1, Phase I Report, July-September 1977

41. Hirasuna, A.R., Bilyen, G.D., Davis, D.L., Stephens, C.A. and Veal, G.R., "Geothermal Elastomeric Materials", Twelve-Month Progress Report, Oct.Sept. 1977, L'Garde, Inc., Newport Beach, CA, SAN/1308-1, Dec. 1977

42. Troiano, A.R. and Hehemann, R.F., Materials Research and Evaluation for Geothermal Corrosion Environments", Case Western Reserve University, Cleveland, Ohio, COO-2602-4, Dec. 1976

43. "Formation Temperature Gauge Feasibility Study, Volume 2", Interim Report, IRT Corporation, San Diego, CA, SAN-0936P48-1, March 1977 
44. "Neutron Formation Temperature Guage and Neutron Activation Analys is Brine Flow Meter", Final Report, IRT Corporation, San Diego, CA, IRT-7021-019, March 1978

45. Lamers, M.D., "Research and Development of Improved Geothermal Well Logging Techniques, Tools and Components (Current Projects, Goals and Status)", Final Report, Measurement Analys is Corporation, Palos Verdes Estates, CA, SAN/1308-1, Jan. 1978

46. McBee, W.D., "Geothermal Down-We11 Instrumentation", Final Report, Sperry Research Center, Sudburry, MA, TID-28701, April 1977

47. "Test Facility for Well Logging Cables", Systems, Science and Software, La Jolla, CA, SAN/1208-1, Feb. 1977

48. Eskesen, J.H., "Study of Practical Cycles for Geothermal Power Plants", Corporate Research and Development, General Electric Company, C00-2619-1, April 1977

49. Starling, K.E., West, H., Iqbal, K.F., Hsu, C.C., Malik, Z.I., Fish, L.W. and Lee, C.0., "Resource Utilization Efficiency Improvement of Geothermal Binary Cycles, Phase II", Univ. of Oklahoma, ORO-4944-7, June-Dec. 1977

50. Jacobs, H.R., Boehm, R.F. and Hansen, A.C., "Application of Direct Contact Heat Exchangers to Geothermal Power Production Cycles", Univ. of Utah, Salt Lake Citj', ID0/1549-8, Jan. 1978

51. Suratt, H.B. and Hart, C.K., "Study and Testing of Direct Contact Heat Exchangers for Geothermal Brines", ERDA ORO-4893-1, DSS Engineers, 1977

52. Allen, C.A. and Grimmett, E.S., "Liquid-Fluidized-Bed Heat Exchanger Design Parameters", Idaho National Engineering Laboratory, ICP-1153, April 1978

53. Kunze, J.F., "Geothermal R \& D Project Report for Period Oct. 1, 1976 to March 31, 1977", Idaho National Engineering Laboratory, TREE-1134, May 1977

54. Austin, A.L. and House, P.A., "New Concepts for Converting the Energy in Low-to-Mediun-Temperature Liquids, With Emphas is on Geothermal Applications", Lawrence Livermore Laboratory, UCRL-52583, Sept. 1978

55. Wilson, J.S., King, J.E. and Bullard, G.R., "Removal of Hydrogen Sulfide from Sinulated Geothermal Brines By Reaction With Oxygen", The Dow Chemical Company, CO0-2797-1, April 1977

56. Urbanek, M.H., "Development of Direct Heat Exchangers for Geothermal Brines", Final Report, Oct. 4, 1977 - June 30, 1978, LBL-8558, UC-66d, Lawrence Berkeley Laboratory, Univ. of California, Berkeley 
57. Phillips, S.L., Doebler, R.A. and Mathur, A.K., "A Study of Brine Treatment", EPRI RP791-1, LBL-6371, May 1977

58. "Monthly Geothermal Report, February 1979", U.S. Geological Survey, Menlo Park, CA, Feb. 1979

59. "63rd Annual Report of the State 0il \& Gas Supervisor", California Division of 0 il \& Gas, Publication No. PRO6, 1977

60. Witham, R. and Reed, M., "Geothermal Wells in the United States", U.S. Geological Survey, May 1976

61. "Known Geothermal Resources Areas (KGRA's) As Classified by the Indicated Area Geologists, Western and Central Regions", U.S. Geological Survey, Menlo Park, CA, Oct. 2, 1978

62. Finney, J.P., "Status Report on the Geysers Project", in Proceedings of the Second Geothermal Conference and Workshop, Taos, NM, June 20-23, 1978, EPRI WS 78-97, P.77, October 1978

63. Hughed, E.E., "Status Report on the Geysers Project", in Proceedings of the Second Geothermal Conference and Workshop, Taos, NM, June 20-23, 1978, EPRI WS 78-97, P.61, October 1978

64. Martinez, A.L., "Status Report on the Geysers Project", in Proceedings of the Second Geothermal Conference and Workshop, Taos, NM, June 20-23, 1978, EPRI WS 78-97, P.67, October 1978

65. "Geothermal Hot Line", 9 (1), (1979)

66. "Geothermal tiot Line", 8 (4), (1978)

67. "Munger Oilogram", P."B", March 21, 1979

68. "EG\&G Starts Department of Energy Geothermal Power Plant Project", Geo-Heat Utilization Center Quarterly Bulletin, 4(1), P.15 Nov. 1978

69. Telephone conversation, Maddox-Phillips, April 19, 1979

70. Telephone conversation, Richards-Phillips, Apri1 18, 1979

71. Telephone conversation, Finlayson-Phillips, April 20, 1979

72. Telephone conversation, Eaton-Tavana, April 18, 1979

73. Telephone conversation, Jacobson-Tavana, April 18, 1979 
74. Telephone conversation, Perry-Tavana, April 18, 1979

75. Telephone conversation, Ingraham-Tavana, Aprif 18, 1979

76. Telephone conversation, Grimlie-Tavana, April 18, 1979

77. "Power Plant Construction Sumnary, Through March 1979", U.S. Geological Survey Monthly Geothermal Report, March 1979

78. "Geothermal Applications And Lease Records Systems, Format A-3", U.S.Geological Survey, Conservation Division, AGS, Menlo Park, CA., 1978.

79. "Bidding History of Competitive Geothermal Lease Sales on Federal Land, Format K-1", U.S.Geological Survey, Conservation Division, AGS, Menlo Park, CA., 1978. 